\title{
External Contestation in the European Union: \\ A Call for Further Investigation at the Nexus of European Institutions, Civil Society Organizations and Transatlantic Relations
}

\author{
H ans Schattle \\ (Yonsei University)
}

\section{$\langle$ CONTENTS〉}

I. Introduction: The European Union as a Venue of External

Contestation

II. Civil Society and the European Union
III. European Public Policy and the United States

IV . Conclusion: Enlarging the Context of Debate on the European Union

- Keywords : European Union, European integration, civil society, EU-U.S. relations

\section{【ABSTRACT】}

The European Union is no longer a mere vehicle of internal contestation over public policies and regulations that affect politics, economics and society within the member states, but it also has emerged as a venue of contestation regarding decisions that impact external stakeholders, especially American multinational corporations. This article illustrates how Brussels has become a major global center of contestation and outlines a research agenda for scholars poised to shed further light along these lines. First the article raises several issues for consideration surrounding the rise of non-profit advocacy groups and civil society organizations in the European Union. It then examines how American multinational corporations and even the United States government have increasingly found themselves on the receiving ends of European Union policies and regulations. The article concludes with some observations about how these two related lines of inquiry, taken in tandem, promise to contribute to scholarly debates regarding the nature of European Union policy making, the onset of global civil society, and the ever shifting state of transatlantic relations. 


\section{I . Introduction: The European Union as a Venue of External Contestation}

The European Union has taken on a much stronger role during the past decade in reshaping processes of economic globalization, especially when it comes to making decisions that affect American-based multinational corporations. At the same time, we have witnessed a remarkable surge of interest in recent years in strengthening the voices of civil society organizations as stakeholders to be accounted for in European Union decision-making processes. ${ }^{1)}$ Although corporate lobbying interests remain far more entrenched in Brussels -- and are certainly more substantially funded -- than nonprofit advocacy groups and civil society organizations, the spectrum of interest group representation has widened considerably as growing numbers of advocacy groups that monitor the corporate sector have intensified attention upon Brussels in recent years. As a result, Brussels increasingly is becoming a key destination not only for interest groups from European Union member states but also stakeholders from around the world, and especially from the United States. In this regard, the European Union is no longer a mere vehicle of internal contestation over public policies and regulations that affect politics, economics and society within the member states, but it also has emerged as a venue of external contestation with stakeholders far beyond Europe's borders.

Presently there is a conspicuous informational gap between assertions from public officials, civil society activists and journalists that European Union institutions are gaining in influence in shaping the global economy -- and that intensified lobbying

1) Definitions of civil society organizations are numerous and varied, and they often disagree on the extent that profit-making corporations are counted as within civil society. Michael Walzer, for instance, has proposed a sweeping definition of civil society as "the space of uncoerced human association and also the set of relational networks - formed for the sake of family, faith, interest, and ideology - that fill this space." Michael Walzer, "The Civil Society Argument," in Gershon Shafir (ed.), The Citizenship Debates (Minneapolis: University of Minnesota Press, 1998), pp. 291-292. Rory Watson and Michael Shackleton, in an article on European Union lobbying and interest groups, offer a concise definition of civil society as "the collection of associations and group activity between the individual and state," but this definition includes private firms, as the key criteria are that organizations are outside the direct control of the state. Rory Watson and Michael Shackleton, "Organized Interests and Lobbying in the EU," in Elizabeth Bomberg and Alexander Stubb (eds.), The European Union: How Does it Work? (Oxford: Oxford University Press, 2003), p. 90. In contrast, I prefer to follow the lead of scholars such as Ann Florini (2000), Margaret Keck and Kathryn Sikkink (1998), as well as the European Commission itself (2000) with an understanding in which the term 'civil society organizations' (or NGOs, non-governmental organizations) applies more narrowly to non-profit voluntary associations, which sometimes are also classified in European Union scholarship as 'public interest groups.' 
efforts in Brussels are associated with this -- and academic research that substantiates such claims. This article, therefore, illustrates how Brussels has become a major global center of contestation and outlines a research agenda for scholars poised to shed further light along these lines. First the article raises several issues warranting further analysis on the rise of non-profit advocacy groups and civil society organizations in the European Union. It then examines how American multinational corporations and even the United States government have increasingly found themselves on the receiving ends of European Union policies and regulations. The article concludes with some observations about how these two related lines of inquiry, taken in tandem, promise to contribute to scholarly debates regarding the nature of European Union policy making, the onset of global civil society, and the ever shifting state of transatlantic relations.

\section{Civil Society and the European Union}

The European Union has managed to take a higher profile in recent years as a key "opportunity structure" for campaigns by interest groups and civil society organizations. As Sonia Mazey and Jeremy Richardson have summarized: "There is now a dense, mature European and transnational interest group system centred upon the European Union." ${ }^{2)}$ The bureaucratic superstructure of the European Commission, especially, has displayed an increasing level of attentiveness to processes of consultation ${ }^{3)}$ with nongovernmental organizations, thereby reinforcing the standing of the Commission and also the European Parliament as hubs of mobilization for interest groups that often gravitate to the units within these institutions that turn out to be the most sympathetic to particular interests. The Commission has taken numerous affirmative steps to promote what it calls a "consultation culture" with interest groups, partly in response to persistent concerns about democratic deficiencies in European Union policy making. The Commission's White Paper on European governance, published in July 2001, issued

2) Sonia Mazey and Jeremy Richardson, "Interest Groups and the Brussels Bureaucracy," in Jack Hayward and Anand Menon (eds.), Governing Europe (Oxford: Oxford University Press, 2003), p. 211.

3) The Commission has published numerous papers that expand upon its intentions to create a stronger culture of consultation within European Union decision making. One seminal discussion paper in this regard, presented in January 2000 by then-Commission President Romano Prodi and Vice President Neil Kinnock, proposed several strategies for improving dialogue between the Commission and civil society organizations. Neil Kinnock and Romano Prodi, "The Commission and Non-Governmental Organisations: Building a Stronger Partnership," European Commission Discussion Paper, 18 January 2000. 
a blanket call to make greater use in policy making of "networks, grassroots organisations and national, regional and local authorities." ${ }^{4)}$

Not only do civil society organizations depend on close access to the Commission and the Parliament, but growing recognition of the need for democratic legitimacy has rendered European Union institutions dependent upon advocacy groups for external validation with regard to public legitimacy. ${ }^{5}$ As Donatella Della Porta has summarized: "In general, the search to legitimate EU institutions has pushed a consensual model, one that has given access to societal actors. In fact, it is increasingly emphasized that the theme of democracy in EU cannot be dealt with only, or principally, in terms of the construction of representative institutions." ${ }^{6}$ Moreover, the Commission now provides considerable funding to civil society organizations, especially environmental groups. ${ }^{7)}$ On the other hand, critics such as Alex Warleigh have argued that by "providing funding for selected NGOs and preferring to work with EU-level umbrella organizations, the Commission risks undermining both the autonomy of NGOs and their suitability as mechanisms of voice for the otherwise disenfranchised." ${ }^{8}$

4) In particular, the White Paper outlined the exhaustive consultative processes involved from 1998 to 2000 in reshaping regulations for the telecommunications industry. This included a two-day public hearing in January 2000, which included 550 participants, as well as detailed communication with stakeholders in April 2000 on the results of the Commission's review of the industry. "European Governance: A White Paper," Commission of the European Communities, 25 July 2001, accessed online on 30 March 2009 at http://ec.europa.eu/governance/white_paper/ index_en.htm.

5) For good accounts of the interplay between the Commission, on the one hand, and civil society organizations on the other, see Holly Jarman, "The Other Side of the Coin: Knowledge, NGOs and EU Trade Policy," Politics 28-1 (February 2008), pp. 26-32; and Brian Hocking, "Changing the Terms of Trade Policymaking: From the 'Club' to the 'Multistakeholder' Model," World Trade Review 3-1 (March 2004), pp. 3-26.

6) Donatella Della Porta, "The Europeanisation of Protest: A Typology and Some Empirical Evidence," paper presented at the annual conference of the European Consortium for Political Research; Marburg, Germany, September 2003, p. 14.

7) Justin Greenwood provides a summary of the so-called ' $G-8$ ' environmental NGOs, which claim to represent more than 20 million members and regularly collaborate in campaigns and share information on advisory forums. The groups also meet collectively with the Commission, usually on a weekly basis, and with the exception of Greenpeace, each group receives funding from the Commission. All in all, environmental organizations within the European Union receive subsidies from the Commission totaling more than 6.5 million euro each year. Justin Greenwood, Interest Representation in the European Union (Basingstoke: Palgrave Macmillan, 2003), pp. 189-199.

8) Warleigh has also argued that the ongoing 'Europeanization' of civil society does not necessarily advance democracy in the European Union, given the lack of democratic governance procedures as well as a lack of widespread political outreach efforts within many advocacy groups. Alex Warleigh, "Europeanizing' Civil Society: NGOs as Agents of Political Socialization," Journal of Common Market Studies 39-4 (November 2001), pp. 622-623. 
Despite the explosion of activity (as well as literature) in recent years intended to propel forward civil society organizations in European Union politics and policy making and understand their impact, it is striking how much more basic information remains necessary for more substantive analysis to proceed. As Robert Kelly pointed out last year in this journal, good documentation of civil society organizations and their activities remains in short supply, and tracking the activities of non-governmental organizations has proven a difficult task. ${ }^{9)}$ Frequent references aside to 10,000 lobbyists $^{10)}$ estimated to $^{2}$ be present in Brussels, the lack of a comprehensive census of interest groups that operate in Brussels poses one immediate obstacle to any effort to measure the extent that the participation of advocacy groups in the European Union has increased over time.11) A detailed head count will also be needed for researchers to conduct a segmentation analysis that would track what kinds of interest groups and what sectors of stakeholders have increased representation in Brussels most dramatically in recent years.

For starters, then, a census that provides thorough and systematic monitoring of the presence and activities of interest groups and civil society organizations in the European Union is needed. This would then facilitate further inquiry into the subset of interest groups from outside European Union member states that have migrated to Brussels in recent years out of recognition of the growing impact of the European Union in shaping the global economy. ${ }^{12)}$ Once these interest groups are identified, further empirical inquiry and analysis is needed with regard to the extent that developments in European Union policy making -- especially, perhaps, competition policy and environmental policy -have prompted civil society organizations from outside the European Union to intensify their efforts in Brussels.

Next awaits the challenge of identifying specific ways in which transnational advocacy

9) Robert Kelly, "Portrait of Global Civil Society at the Bretton Woods Institutions: Civil Society Dialogue Participation, 2000-2007," The Korean Journal of International Relations 48-5 (December 2008), pp. 51-80.

10) This figure appears to date back to a 1992 report by the European Commission, which estimated there were about 3,000 interest groups in Brussels. During interviews conducted in the course of preparing this article, various officials and activists estimated that the actual count of lobbyists at present in Brussels has increased to 12,000 to 13,000 -- and that representatives from civil society organizations make up no more than 500 of these lobbyists, leaving them vastly outnumbered by corporate interests.

11) There is some recent, albeit limited progress toward a head count. In June 2008, the European Commission introduced an online "Register of Interest Representatives," though as of March 30, 2009, only 1,235 individuals had registered. "European Commission Register of Interest Representatives," accessed online on 30 March 2009 at http://ec.europa.eu/civil_society/index_en.htm.

12) This would include both interest groups from specific countries as well as interest groups that would be classified more broadly as transnational. 
groups have influenced substantially the shaping of European Union public policy. Once the contours of the transnational advocacy community in Brussels become clearer, what is the extent that decisions in the Commission and the Parliament can be attributed, at least in part, to the voices of civil society activists? What sorts of plausible cause-andeffect relationships can be identified? In some respects, these questions converge with Pierre Bouven's efforts to construct a theoretical model explaining the degree of access (though not necessarily influence) of business interests to European institutions. ${ }^{13)}$ Moreover, it would be illuminating to identify and compare the relative impacts, with regard to influencing policy making, of interest groups based primarily outside the European Union versus interest groups based in the member states of the European Union. And to what extent have interest groups in Brussels from outside the corporate sector gained in influence relative to corporate lobbyists? ${ }^{14)}$

The larger matter at stake here, with respect to European Commission decisions, is to what extent greater institutional efforts toward "consultation" in recent years have offset Robert Geyer's grim conclusion that "EU social NGOs have generally remained small, poor and weak organisations exercising only a limited degree of influence over the EU policy process and struggling to co-operate with each other on fundamental social issues and political strategies. ${ }^{15)}$ Geyer attributes the relative lack of support and lack of cooperation among social NGOs in part to considerable stratification among advocacy groups in terms of resources, funding, access to decision makers and incompatible missions among various civil society organizations.

Is it now becoming feasible, at last, for scholars of the European Union to measure more effectively and compare, over time, the relative influence of each the various segments of interest groups operating in Brussels? Donatella Della Porta has proposed similar questions for further inquiry -- in her case, with respect to the relative influence of interest groups that are powerful within the domestic politics of member states, such as corporate lobbying interests, as opposed to interest groups that are less powerful

13) Pierre Bouven, "Corporate Lobbying in the European Union: The Logic of Access," Journal of European Public Policy 9-3 (2002).

14) During interviews conducted in the course of writing this article, several lobbyists within civil society organizations indicated that they do not believe civil society is becoming more powerful relative to business, and that non-profit advocacy groups remain outgunned, in a sense, by corporate lobbying firms and industry associations. If this is the case, questions then follow about the extent that disparities in resources continue to undercut the influence of civil society organizations even as they more readily are forming alliances, if not outright partnerships, with the European Union policymakers on particular issues.

15) Robert Geyer, "Can European Union Social NGOs Co-operate to Promote EU Social Policy?" Journal of Social Policy 30-3 (July 2001), p. 478. 
within the member states but are nevertheless gaining recognition within European Union institutions. As Della Porta has noted: "In particular, do European institutions balance or strengthen the unequal domestic representation of interest?... It might be the case that the EU will strengthen those who are already nationally strong while, in fact, marginalising the weak even more than they have already been marginalised at the national level. ${ }^{\left.{ }^{16}\right)}$ The challenge for scholars, then, is to chart a course for further investigation and analysis in which the relative influence of particular segments of interest groups in Brussels can be clarified and classified.

\section{European Public Policy and the United States}

Clearly the very existence of the European Union and its earlier incarnations has been intertwined with United States involvement since Dean Acheson, as Secretary of State in the Harry S. Truman administration, played a crucial role behind the scenes in encouraging France's foreign minister, Robert Schuman, to take the first steps leading to the formation of the European Coal and Steel Community. ${ }^{17)}$ For the first halfcentury of European integration, common perceptions of a united Europe from the United States have emphasized paths toward peace, economic development and international collaboration; it remains to be seen whether common American perceptions for the next fifty years will emphasize the European Union primarily as a strategic partner or as a rival superpower. The continuing evolution in the European Union's role as a global economic actor has redefined the transatlantic relationship.

Recognition of the European Union's growing power over American business moved to the center of public debate in the United States this decade with two landmark cases from the European Commission's competition policy directorate. First, in 2001, the Commission vetoed the merger plans of General Electric and Honeywell even after the U.S. $\$ 45$ billion deal had already been approved by the antitrust division of the United States Department of Justice. Then, in 2004, the Commission fined Microsoft nearly 500 million euro on grounds that it was blocking its competitors out of the market by bundling software within its Windows operating system. As of May 2009, the Microsoft case remained open, with the Commission seeking additional fines of nearly 900 million euro and expanding the scope of its investigation into other Microsoft products, while

16) Della Porta, supra note 6, pp. 14-15.

17) For an interesting account of Acheson's role behind the scenes, see William I. Hitchcock, The Struggle for Europe (New York: Anchor Books, 2003), pp. 151-152. 
an appeal from Microsoft remained pending before the European Court of First Instance. Just before this article went to press, the European Commission fined Intel more than 1 billion euro for allegedly abusing its dominant position in the computer chip market. ${ }^{18)}$

In the aftermath of the blocked GE/Honeywell merger, an article published in the Wall Street Journal, brought home to an American public normally oblivious to the processes of European Union policy making the extent to which more and more rules governing the global economy are now set in Brussels, not Washington -- and how American businesses are changing their operations and modifying practices in order to maintain access to the European market. Case studies in the article included an Indiana farmer avoiding the use of insect-resistant, genetically modified corn seeds, the McDonald's Corporation's decision to stop including plastic toys in its Happy Meals, and United Technologies Corporation's redesign of its air conditioners to meet more stringent European Union environmental standards on recycling. As Maja Wessels, a lobbyist based in Brussels (at the time with United Technologies) told the Journal: "Twenty years ago, if you designed something to U.S. standards, you could pretty much sell it all over the world. Now the shoe's on the other foot." ${ }^{19)}$ There is also growing recognition in international business circles that American corporations have chosen to follow the European Union's electronic privacy standards, which are more stringent than United States standards in affirming the rights of individuals to know what data has been collected about them online and to force corporations to correct or delete incorrect information.

Such developments regarding gravitation in the corporate sector toward European Union standards issue a new challenge to scholars interested in the evolution and impact of European Union institutions in shaping not only economic and political integration on the continent but also the character of the global economy in years to come. We can see that more and more American multinationals are defaulting to European Union standards in order to smooth the way for continued global expansion, and we can see that growing numbers of civil society organizations are in turn setting up shop in Brussels, elevating the European capital to a key venue of contestation and regulation over the future direction of the world economy. However, the precise extent that Brussels truly is gaining influence relative to Washington as a power center within the global economy awaits further clarification. Likewise, the extent that interest groups -- and especially civil society organizations -- can be regarded as contributing to this possible

18) James Kanter, “Europe Fines Intel $\$ 1.45$ Billion in Antitrust Case," New York Times, 13 May 2008.

19) Brandon Mitchener, "Increasingly, Rules of Global Economy Are Set in Brussels," Wall Street Journal, 23 April 2002. 
expansion of relative influence of the European Union also awaits further empirical study.

Since European Union policy now has the potential to constrain not only multinational corporations based in the United States but also contradict United States government policy, it is pertinent to explore the extent that the United States government and the United States corporate sector have become, in effect, prominent and permanent external constituents of the European Union, in terms of being held accountable to at least a limited number of European Union standards. ${ }^{20)}$ To be sure, one litmus test of a formative external constituency relationship between the European Union and the United States is the growing presence of lobbyists in Brussels representing American corporations and civil society organizations. Indeed, one may argue credibly that some European Union decisions carry as much significance for the United States as they do for the European Union's own member states. Suggestions along these lines -- or allegations, depending on one's point of view -- have emerged increasingly in public debate during the past two years. Consider the angry reaction from then-United States House Speaker Dennis Hastert in early 2004, after European Union Trade Commissioner Pascal Lamy managed to pressure the U.S. government to eliminate a hefty tax break for American exporters by threatening to impose U.S. $\$ 4$ billion trade sanctions against the United States. In Hastert's words: "My gut feeling about this is we fought a revolution 230 years ago to stop Europeans from telling us how we have to tax in this country, and it puts the hair up on the back of my neck that we have to consider this at all. But we have to do it." ${ }^{21)}$

That the United States is becoming, in essence, the world's most prominent external stakeholder of the European Union seemed especially apparent with the implementation of the new REACH standards ('Registration, Evaluation, Authorisation and Restriction of Chemicals') implemented in 2007 by the European Commission to regulate the production and uses of chemicals, many of them toxic substances. As Mark Schapiro noted in a widely read article in The Nation, during public debate over the REACH standards:

20) Of course, one can argue that the sheer volume of bilateral trade between the United States and European Union member states renders both the United States and the European Union external constituents of each other. Indeed, supporting the idea that the USA and the EU are mutual external constituents, merger officials from both entities have collaborated on 'best-practice' guidelines and agreed to share information on pending future cases in hope of avoiding future conflicting decisions on landmark mergers such as the failed bid from General Electric and Honeywell. Patrick Blum, "EU and US Regulators to Meet More Often," Financial News, 15 December 2002.

21) Dennis Hastert, quoted by Nicholas Kulish, "Euro Brash: Why George W. Bush Takes Orders from Pascal Lamy," Washington Monthly, 15 April 2004. 
The US chemical industry, like other American industries, has been discovering that a presence in Brussels is now a must -- and has had to learn new ways to exert influence in a governing institution with three chambers, twenty-five countries and twenty national languages, and in which the usual cocktail of campaign contributions, arm-twisting and seduction are neither warmly received nor, in the case of campaign contributions, legal. ${ }^{22}$

The same news article quoted lobbyists from the American Chemical Council, which opposed the higher standards, conceding that while they were accustomed to focusing on individual member states within Europe, only recently had they begun monitoring and lobbying the European Union as a single entity with regulatory authority. The Bush administration, with considerable backing from the business sector, opposed the REACH standards to the point that then-Secretary of State Colin Powell sent out a cable to all United States embassies in European Union member states claiming that REACH could adversely affect the majority of the U.S. $\$ 150$ billion in annual American exports to the European Union.

Supporters of the regulations, in contrast, argued that they were making their way to Brussels with public opinion on their side, and that the regulations would point to an example of globalization raising, rather than lowering, standards of conduct for corporations. In the words of Charlotte Brody of the interest group Health Care Without Harm, which supported REACH on grounds that the regulations would reduce toxic substances in hospital supplies: "We are putting more resources into Europe than we otherwise would have done. We desperately need the EU to be raising the bar and show what is possible." ${ }^{23)}$ While such anecdotal evidence is often quite salient and even compelling at times, more substantive research is needed for decisive conclusions about the external impact of European Union decisions on the United States compared, both in absolute and in relative terms, with the internal impact of European Union decisions within the member states.

A related issue revolves around the extent an emerging 'leapfrog to Brussels' dynamic can be detected among some interest groups based in the United States that see more potential for political victory on key issues in Brussels than in Washington. Just as myriad interest groups, political parties and regional governments within European Union member states have managed, through the years, to leapfrog to Brussels and bypass national governments that were not aligned with their positions or objectives, the same

22) Mark Schapiro, "New Power for Old Europe," The Nation, 9 December 2004.

23) Charlotte Brody, quoted by Otto Pohl, "Advocates for Change in U.S. Environmental Law Are Turning to EU," New York Times, 6 July 2004. 
dynamic now appears under way among various non-governmental organizations looking to use European Union policies and regulations as a means of essentially overriding United States economic policies that often are less restrictive. For example, the United States-based Campaign for Safe Cosmetics (http://www.safecosmetics.org/) set up shop in Brussels specifically to lobby for approval of the aforementioned REACH regulations. Even after the implementation of REACH, this wide coalition of public interest groups, continues to lobby corporations to follow European Union standards prohibiting the use of known or suspected carcinogens, mutagens and reproductive toxins from cosmetics products. The global environmental organization Greenpeace also operates an active office in Brussels that coordinates its support of more stringent European environmental standards,

Both sides of the ideological divide between liberals and conservatives in the United States have incentives to emphasize -- and inflate, at times -- the extent that the European Union might be gaining in power relative to Washington in setting global standards and regulations affecting multinational corporations. While left-wing commentators can be quick to frame Brussels policymakers as providing a welcome check on American capitalism, right-wing commentators can all too readily drum up domestic public support simply by making allegations that the European Union is aligning itself in opposition to American national interests. Moreover, I would add that the 'leapfrog to Brussels dynamic' is by no means restricted to reformist civil society organizations; Disney, Sun Microsystems, and United Technologies all can serve as examples of corporate actors that leapfrogged to Brussels to challenge corporate rivals -and in some instances, challenged them much more powerfully than proved feasible within United States government regulatory frameworks.

If the United States is indeed emerging as a prominent and permanent external constituent accountable to European Union norms, and if the increasing migration of American interest groups to Brussels serves as an indicator of this state of affairs, still more sweeping questions present themselves: In what policy areas can the European Union be regarded as superseding the United States in setting the standards for the global economy?24) In some respects, it might seem premature to pose this question, since the regulatory apparatus of the European Union is still widely regarded as far less

24) As Walter Mattli and Tim Büthe have investigated and analyzed with great rigor and detail, differences in domestic institutional structures matter -- especially when comparing standards from the United States and the European Union -- in determining which sets of standards become the most prominent internationally. Walter Mattli and Tim Büthe, "Setting International Standards: Technological Rationality or Primacy of Power?" World Politics 56-1 (October 2003), pp. 1-42. 
developed than the tentacles of the United States executive branch. As Johan P. Olsen has noted, the European Union's relative capacity for governing remains substantially more modest than most nation-states, and European Union institutions operate within a ceiling of 1.27 percent of GNP from the member states. ${ }^{25}$ ) Nevertheless, mounting evidence suggests that the momentum is shifting to Brussels in areas such as food safety, accounting standards, telecommunications policy, and, of course, corporate mergers and acquisitions. The question, once again, is how to systematically quantify and track such rising momentum? Obviously any reliable indicator of the relative strength of Brussels also has to measure the relative strength of Washington -- and provide insight into how the relative strength among actors such as the European Union, the United States, and other powerful nation-states and international organizations has shifted over time.

At least two additional questions are relevant in this regard: To what extent is the European Union challenging the economic sovereignty of the United States? ${ }^{26)}$ And to come full circle with respect to civil society, if the EU is challenging the sovereignty of the United States at least in limited respects, what is the extent that this can be attributed to the workings of transnational advocacy groups? If the European Union is indeed beginning to emerge as an external check on the United States government, what is the impact upon the strategies of transnational advocacy groups? Is it possible that the offices of European Union bureaucrats provide more fertile ground for socalled 'anti-globalization activists' than the streets outside summit meetings of international economic institutions? At the very least, even if it should prove premature to claim that the European Union has become a check on United States economic sovereignty or that the United States has, in effect, become an external constituent of the European Union, at the very least the EU has emerged as an additional channel of accountability for the United States government as well as multinational corporations based in the United States. What, then, are the implications for United States global policy as well as the ways the United States government deploys its diplomatic resources? Already, calls are emerging in public debate for the realignment of United States government personnel in Europe -- shifting the emphasis away from bilateral relations with national governments in favor of a primary focus on the European Union.

25) Johan P. Olsen, "Survey Article: Unity, Diversity and Democratic Institutions: Lessons from the European Union," Journal of Political Philosophy 12-4 (October 2004), pp. 461-495.

26) Clearly this question commonly has been asked in the reverse during the past 50 years: What is the extent that the United States challenges the economic sovereignty of European Union member states as well as the Union as a whole? 


\section{Conclusion: Enlarging the Context of Debate on the European Union}

Further inquiry into how the growing presence of civil society organizations in Brussels, coupled with progressions in European Union policy making, are together transforming the state of relations between the European Union and the United States promises to contribute to a number of ongoing academic debates that cut across the traditional subfields in political science and international relations. Tracing the roots of the expanded presence and evolving strategies of advocacy groups in Brussels promises to help propel debate on the nature of the European Union further past the longstanding rifts between intergovernmentalists and supranationalists ${ }^{27}--$ and also beyond approaches that emphasize collaboration primarily among political elites -- and toward perspectives that emphasize political contention and activity within multiple public spheres. This approach to the institutional evolution of the European Union mirrors what Doug Imig and Sidney Tarrow call an interactionist' perspective in which any emergence of a European polity will amount to "a long-term outcome of conflict and cooperation between and among nonstate and public actors" often in the context of pressure on domestic political institutions with regard to European issues. ${ }^{28)}$

Tracing the 'leapfrog to Brussels dynamic' from the perspective of the United States promises to expand upon the European Union regional policy scholarship (especially prolific during the 1990s) that documented the extent that relatively peripheral political actors and economically disadvantaged cities and regions within member states looked to Brussels for more favorable policy outcomes as well as economic development

27) Maria Green Cowles has argued strongly that liberal intergovernmentalism, especially, fails to account for ways in which interest groups (from all sectors) "participate simultaneously in international and domestic politics... While liberal intergovernmentalists rightly call on scholars to better specify the conditions under which non-state actors' representation matters, liberal intergovernmentalism in turn would be strengthened if it developed a more robust understanding of the multiple arenas in which non-state actors participate." Maria Green Cowles, "Non-State Actors and False Dichotomies: Reviewing IR/IPE Approaches to European Integration,” Journal of European Public Policy 10-1 (2003), pp. 105-106.

28) Doug Imig and Sidney Tarrow, eds., Contentious Europeans: Protest and Politics in an Emerging Polity (Lanham, MD: Rowman \& Littlefield, 2001), p. 4. Likewise, Donatella Della Porta also has observed that research on protests within member states tends to reinforce an intergovernmentalist view that gives priority to nation-states, while the activities of public interest groups targeting European institutions "point, instead, to the emergence of a new polity and the creation of a new politics." (Della Porta, supra note 6, p.2) While much of the literature on contentious politics seems to emphasize activity among interest groups, social movements and stakeholders based within the European Union -- and documents shifts of contentious politics toward European-wide issues, with internal political and social 
funding. ${ }^{29)}$ Tracing recent policy developments, meanwhile, especially with regard to competition policy and environmental policy-promises to illustrate how areas traditionally regarded as internal policy making also amount to external policy making of the European Union; that just as the very existence of the European Union signifies how domestic politics and international relations have become increasingly intertwined, the impacts of European Union policy making in non-member states -- or, prospective 'external constituents,' as I tentatively have labeled the United States in this article -provide further illustrations of how the boundaries between internal policy and external policy are considerably more ambiguous than historically perceived. Is it sensible for researchers to maintain tight distinctions between internal policy and external policy of the European Union, or do these policy realms increasingly overlap?

The research agenda outlined here also promises to contribute to the renewed debate about the fluid state of transatlantic relations. In particular, I believe that simply framing the questions here provides a rejoinder of sorts to Robert Kagan's much debated thesis that the European Union amounts to the renunciation of power politics. On the contrary, I would argue that the European Union exemplifies the redeployment of power politics, and examining the extent that the United States can be classified as an emerging external constituent of the European Union can further illustrate this. Moreover, this inquiry can contribute to broader debates on the sorts of external checks and balances that are becoming more powerful in containing what many scholars and historians now label an American empire. Finally, tracing the roots and the impacts of transnational advocacy networks in the European Union, and elaborating in greater depth and detail on how exactly Brussels has become a key outpost for civil society organizations, interest groups and social movements can shed further light upon how the sometimes elusive notion of a global civil society is emerging in practice. ${ }^{30)}$

actors -- the questions posed in this article point to prospects for contentious politics to be emerging among external actors, as well.

29) For two classic competing interpretations on how European Union regional development policy exemplifies EU governance, see Liesbet Hooghe, ed. Cohesion Policy and European Integration: Building Multi-Level Governance (Oxford: Oxford University Press, 1996), and Ian Bache, The Politics of European Union Regional Policy: Multi-Level Governance or Flexible Gatekeeping? (Sheffield: University Association of Contemporary European Studies/ Sheffield Academic Press, 1998).

30) Or in related parlance, a notion of cosmopolitics, as advocated by European Trade Commissioner Pascal Lamy, as signifying "a new way of legitimizing (international) economic governance by involving citizens in the organization of governance and mediation between different interests." Pascal Lamy, "Europe and the Future of Economic Governance," Journal of Common Market Studies 42-1 (March 2004), p. 13. 


\section{REFERENCES}

Bache, Ian. The Politics of European Union Regional Policy: Multi-Level Governance or Flexible Gatekeeping? Sheffield: University Association of Contemporary European Studies/Sheffield Academic Press, 1998.

Blum, Patrick. "EU and US Regulators to Meet More Often." The Financial News (15 December 2002).

Bouven, Pierre. "Corporate Lobbying in the European Union: The Logic of Access." Journal of European Public Policy 9-3 (2002).

Commission of the European Communities. "European Governance: A White Paper" (25 July 2001).

. "Consulation Document: Towards a Reinforced Culture of Consultation and Dialogue” (5 June 2002).

Cowles, Maria Green. "The EU Committee of AmCham: The Powerful Voice of American Firms in Brussels.” Journal of European Public Policy 3-3 (1996).

"Non-State Actors and False Dichotomies: Reviewing IR/IPE Approaches to European Integration.” Journal of European Public Policy 10-1 (2003).

Della Porta, Donatella. "The Europeanisation of Protest: A Typology and Some Empirical Evidence." Paper presented at the annual conference of the European Consortium for Political Research, Marburg, Germany, September 2003.

Florini, Ann M., ed. The Third Force: The Rise of Transnational Civil Society. Washington: Carnegie Endowment for International Peace, 2000.

Fuller, Thomas. "As EU Gains in Heft, Washington's Diplomacy Slowly Changes." International Herald Tribune (20 December 2002).

Geyer, Robert. "Can European Union Social NGOs Co-operate to Promote EU Social Policy?” Journal of Social Policy 30-3 (July 2001).

Greenwood, Justin. Interest Representation in the European Union. Basingstoke: Palgrave Macmillan, 2003.

Hitchcock, William I. The Struggle for Europe. New York: Anchor Books, 2003.

Hocking, Brian. "Changing the Terms of Trade Policymaking: From the 'Club' to the 'Multistakeholder' Model.” World Trade Review 3-1 (March 2004).

Hooghe, Leisbet and Gary Marks. "Birth of a Polity: The Struggle over European Integration," in Herbert Kitschelt et al, eds. The Politics and Political Economy of Advanced Industrial Societies, Cambridge: Cambridge University Press, 1995. 
Hooghe, Liesbet, ed. Cohesion Policy and European Integration: Building Multi-Level Governance. Oxford: Oxford University Press, 1996.

Imig, Doug and Sidney Tarrow, eds. Contentious Europeans: Protest and Politics in an Emerging Polity. Lanham, MD: Rowman \& Littlefield, 2001.

Jarman, Holly. "The Other Side of the Coin: Knowledge, NGOs and EU Trade Policy." Politics 28-1 (February 2008), pp. 26-32.

Kagan, Robert. "Power and Weakness." Policy Review 113 (June 2002).

Keck, Margaret E. and Kathryn Sikkink. Activists beyond Borders: Advocacy Networks in International Politics. Ithaca: Cornell University Press, 1998.

Kelly, Robert. "Portrait of Global Civil Society at the Bretton Woods Institutions: Civil Society Dialogue Participation, 2000-2007." The Korean Journal of International Relations 48-5 (December 2008).

Kinnock, Neil and Romano Prodi. "The Commission and Non-Governmental Organisations: Building a Stronger Partnership." European Commission Discussion Paper (18 January 2000).

Kulish, Nicholas. "Euro Brash: Why George W. Bush Takes Orders from Pascal Lamy." Washington Monthly (15 April 2004).

Lamy, Pascal. "Europe and the Future of Economic Governance." Journal of Common Market Studies 42-1 (March 2004).

Loewenberg, Samuel. "Business Meets its Match.” The American Prospect (July 2003).

Mattli, Walter and Tim Buithe. "Setting International Standards: Technological Rationality or Primacy of Power?” World Politics 56-1 (October 2003).

Mazey, Sonia and Jeremy Richardson. "Interest Groups and the Brussels Bureaucracy," in Jack Hayward and Anand Menon, eds. Governing Europe. Oxford: Oxford University Press, 2003.

Mitchener, Brandon. "Increasingly, Rules of Global Economy Are Set in Brussels." Wall Street Journal (23 April 2002).

Olsen, Johan P. "Survey Article: Unity, Diversity and Democratic Institutions: Lessons from the European Union.” Journal of Political Philosophy 12-4 (October 2004).

Pohl, Otto. "Advocates for Change in U.S. Environmental Law Are Turning to EU." New York Times (6 July 2004).

Reid, T. R. The United States of Europe: The New Superpower and the End of American Supremacy. New York: Penguin, 2004.

Rifkin, Jeremy. The European Dream: How Europe's Vision of the Future Is Quietly Eclipsing the American Dream. New York: Jeremy P. Tarcher, 2004. 
Schapiro, Mark. "New Power for Old Europe." The Nation (9 December 2004).

Walzer, Michael. "The Civil Society Argument," in Gershon Shafir, ed. The Citizenship Debates. Minneapolis: University of Minnesota Press, 1998.

Warleigh, Alex. "Europeanizing' Civil Society: NGOs as Agents of Political Socialization." Journal of Common Market Studies 39-4 (November 2001).

Watson, Rory and Michael Shackleton. "Organized Interests and Lobbying in the EU," in Elizabeth Bomberg and Alexander Stubb, eds. The European Union: How Does it Work? Oxford: Oxford University Press, 2003. 